\title{
Impact of Clause 49 of Listing Agreement of Securities and Exchange Board of India on Corporate Governance
}

\author{
Kumudha Rathna*
}

\section{Abstract}

Corporate governance is the current exhortation in India as well as the world over. As an offshoot of economic liberalization, global investment in the form of foreign direct investment and foreign institutional investment have gained momentum leading to vast economic growth in India. On the other hand, major corporate scams that have occurred worldwide in recent times, have revealed that the need for strict supervision and scrutiny over corporate management and governance is a sin quo non for the protection of stakeholders and the growth of the nation which has to compete with the multinational companies in the global arena.

Further, in India, most of the listed companies, and substantially all billion-dollar companies, are family-run. A particular characteristic of the Indian corporate landscape, however, is a tendency for individuals (and their families) to establish large interlocking networks of subsidiaries and sister companies that include partially owned, publicly listed companies. Such pyramidal structures can lead to severely inequitable treatment of shareholders. The extent of this control is frequently opaque to outsiders and undisclosed by insiders. A particular need for effective corporate governance in India is, therefore, to encourage the dynamism and growth of family.

* Assistant Professor, Postgraduate Department-Business Law, The Tamil Nadu Dr Ambedkar Law University, Chennai 
The inclusion of Clause 49 by Securities Exchange Board of India (SEBI) in the listing agreement between companies endeavouring to have their securities listed in stock exchanges has impacted the modality of corporate management.

This research paper examines the impact of clause 49 of listing agreement of SEBI on corporate governance.

Keywords: Clause 49, Corporate Governance, Listing Agreement, SEBI

\section{Introduction}

Corporate governance is the current exhortation in India as well as the world over. It has in its ambit the set of processes, customs, policies, laws, and institutions affecting the way in which a corporation is directed, administered, or controlled. Corporate governance has gained tremendous importance in the recent past especially after the second half of 1996. Two main reasons for this upsurge are:

1. Economic liberalization and deregulation of industry \& business, and

2. Demand for new corporate governance in stricter compliance with the law of the land.

\section{Developments in India}

The initiative taken by government in 1991, aimed at economic liberalization and globalization of the domestic economy, led India to initiate reform process in order to suitably respond to the developments taking place worldwide. ${ }^{1}$ The report of the Cadbury Committee on the financial aspects of corporate governance in U.K has given a fillip to the debate on corporate governance in India. ${ }^{2}$

\footnotetext{
1 Rajesh Chakrabarti, The FinANCIAL SECTOR IN INDiA - EMERgING ISSUES 210 (1st ed. 2006).

2 K.M. GHOSH \& DR. K.R. CHANDRATRE, COMPANY LAW WITH SECRETARIAL PRACTICE 3371 (Bharat Law House 13th ed. 2006). 
Consequently, the Confederation of Indian Industry (CII), Associated Chambers of Commerce and Industry (ASSOCHAM), Securities and Exchange Board of India (SEBI) constituted committees to recommend certain initiatives which can be taken up in relation to corporate governance. CII took a special initiative on corporate governance. The objective was to develop and promote a code of corporate governance to be adopted and followed by the Indian Companies, be these in the private sector, public sector, banks, or financial institutes, all of which are corporate entities. The final draft of the said Code was widely circulated in 1997. The Code released in April 1998 and it was called "Desirable Corporate Governance Code."

Following CII's initiative, the SEBI set up a committee under the Chairperson of Kumar Mangalam Birla to promote and raise the standards of corporate governance. The Committee in its report observed that "strong corporate governance is indispensable to resilient and vibrant capital markets and is an important instrument of investor's protection. It's the blood that fills the veins of transparent corporate disclosure and high quality accounting practices; it's the muscle that moves a viable and accessible financial reporting structure." 3

The recommendation of the Kumar Mangalam Birla Committee led to the inclusion of Clause 49 in the Listing Agreement in the year 2000. These recommendations aimed at improving the standards of the corporate governance, and are divided into mandatory and non-mandatory recommendations. The said recommendations have been made applicable to all the listed companies with the "paid-up capital" of Rs. 3 crores and above or net worth of Rs. 25 crores or more at any time in the history of the company. The ultimate responsibility for putting the recommendations into practice lies directly with the Board of Directors and the management of the company.

In the year, 2002 SEBI analyzed the statistics of compliance with the Clause 49 by listed companies and felt that there was a need to look

3 Report of the Kumar Mangalam Birla Committee on Corporate Governance, web.sebi.gov.in/commreport/corpgov.html (last visited Aug. 16, 2012). 
beyond mere systems and procedures if corporate governance was to be made effective in protecting the interest of investors. SEBI therefore constituted a committee under the Chairmanship of Shri N.R. Murthy for reviewing implementation of the Corporate Governance Code by listed companies and issue revised Clause 49 based on its recommendations. ${ }^{4}$

The matter of corporate governance has acquired much prominence consequent to the flow of foreign investment into the corporate sector of India. Foreign investors, whether in the form of FDI (foreign direct investment) or FII (foreign institutional investment), desire that corporate management and governance be mandatorily required by law to be done in an efficient and transparent manner. Accordingly, SEBI has revised Clause 49 of the Listing Agreement of the Indian Stock Exchange with effect from 31 December 2005. It has been formulated for the improvement of corporate governance in all listed companies.

- As per Clause 49, for a company with an Executive Chairman, at least $50 \%$ of the Board of Directors should comprise independent directors. In the case of a company with a non-executive Chairman, at least one-third of the board should be independent directors.

- It would be necessary for chief executives and chief financial officers to establish and maintain internal controls and implement remediation and risk mitigation towards deficiencies in internal controls, among others.

- Sub-clause VI (ii) of Clause 49 requires all companies to submit a quarterly compliance report to stock exchange in the prescribed form. The clause also requires that there be a separate section on corporate governance in the annual report with a detailed compliance report.

- A company is also required to obtain a certificate either from auditors or practicing company secretaries regarding compliance of conditions as stipulated, and annex the same to the director's report.

4 The INSTITUTE OF COMPANy SECRETARIES OF INDIA, CORPORATE Governance (Modules Of Best Practices) 13 (5 $5^{\text {th }}$ ed. 2006). 
- The clause mandates composition of an audit committee; one of the directors is required to be "financially literate."

- It is mandatory for all listed companies to comply with the clause by 31 December 2005.

Clause 49 of the SEBI Guidelines on corporate governance as amended on 29 October 2004 has made major changes in the definition of independent directors, strengthening the responsibilities of audit committees, improving quality of financial disclosures, including those relating to related party transactions and proceeds from public/ rights/ preferential issues. Certain nonmandatory clauses like whistle blower policy and restriction of the term of independent directors have also been included.

By Circular dated 8 April 2008, the SEBI amended Clause 49 of the Listing Agreement to extend the 50\% independent directors rule to all boards of directors where the non-executive chairman is a promoter of the company or related to the promoters of the company. At the end of the first India Corporate Week in December 2009, the Ministry of Corporate Affairs issued new Corporate Governance Voluntary Guidelines and new Corporate Social Responsibility Voluntary Guidelines. Non-compliance with the provisions of corporate governance in clause 49 would invite penalties such as suspension of trading and delisting from the stock exchange. While SEBI can delist a company for non-compliance, even individual stock exchange has been empowered to suspend the trading of shares of defaulting companies.

\section{Lacunae in the Existing Clause 49 of Listing Agreement on Corporate Governance}

Clause 49 of the Listing Agreement has changed largely the structure and working of the companies. ${ }^{5}$ Introduction of corporate governance has infused enhanced transparency and ethics into the structure and working of companies. However, it is still a tough and long road ahead. Many loopholes and lacunae have to be taken

5 Vedant Shukla, Corporate Governance at Crossroads, THE PRACTICAL LAWYER, Sept. 7, 2007, http://www.ebc- india.com/ practicallawyer/ index2.php?option $=$ com_content\&itemid $=5 \&$ do_pdf $=1 \&$ id $=7007$. 
care of in order to ensure better performance and implementation of corporate governance. For example, the present code allows the promoters to gain/retain control over the companies. The main implication of the share pattern is that leaving decision making to companies' share-holders and their boards in effect, means giving full freedom to the promoters. ${ }^{6}$ In the present ownership pattern there is hardly any threat to incumbent managements of vast majority of companies. In most companies, institutional investors, who could have played the "monitoring role," have either no presence or are only marginal players. The problem appears to be more severe in the case of smaller companies, which are generally avoided by institutional investors. ${ }^{7}$ There is also a possibility of the liberalized Companies Act, 1956 encouraging inter-corporate investments, which reduces the risk borne by the promoters while increasing their hold. It may seem that India has missed an opportunity to build an ownership structure, which while making the promoters genuinely interested, also would have kept them on a tight leash. ${ }^{8}$

Instances have been found where companies overlooked obvious linkages to confer independence on individuals probably taking advantage of this freedom. Promoters being firmly in saddle, the slim possibility of genuine independent directors getting elected to corporate boards have receded even further. It should be kept in mind that the companies are being rather forced to introduce such directors. As a result of this, companies have found out a way to avoid the probable problems faced by the induction of independent directors. In many companies, the promoters re-designated themselves as the non-executive chairman so that the company does not have to reserve half of the Board seats for independent directors. ${ }^{9}$ But the major problem is that some companies are designating the promoters' father-in-law, mother's brother or wife's brother as non-executive chairman as they are not regarded

${ }^{6} \mathrm{Id}$.
${ }^{7} \mathrm{Id}$.
${ }^{8} \mathrm{Id}$.
${ }^{9} \mathrm{Id}$.
132 
as relatives under the Companies Act, 1956. SEBI had to make the Corporate Governance Code somewhat more palatable to them. It is, therefore, debatable as to what extent the efforts at improving corporate governance would succeed in the face of high promoter stakes. In fact, the prescribed minimum public shareholding is low that the management can get through even special resolution without any hindrance. It is easy to let promoters accumulate their holding but difficult to force them to bring it down. Effective steps should be taken at the entry point itself to curb the problem. ${ }^{10}$

\section{Conclusion}

"Law without loyalty cannot strengthen the bonds of Empire." 11 In an energetic and lively environment, systems of corporate governance need to be continually evolved. The following lines from Narayan Murthy Committee Report aptly conveys this:

"Corporate governance is beyond the realm of law. It stems from the culture and mindset of management, and cannot be regulated by legislation alone. Corporate governance deals with conducting the affairs of a company in such a way that there is fairness to all stakeholders and that its actions benefit the greatest number of stakeholders. It is about openness, integrity and accountability. What legislation can and should do is to lay down a common framework - the 'form' to ensure standards. The 'substance' will ultimately determine the credibility and integrity of the process. Substance is inexorably linked to the mindset and ethical standards of management." 12

Development and maintenance of a robust corporate governance framework therefore calls for the commitment of numerous persons and institutions throughout society. Legislatures, regulatory bodies, courts and self-regulating professional

${ }^{10} \mathrm{Id}$.

11 Thomas Mohr, Law without Loyalty- The abolition of the Irish appeal to the Privy Council 37, THE JURIST 187, 2002.

12 Report of the Narayan Murthy Committee, http:// www.docstoc.com /docs/17063069/corporate-governance (last visited Aug. 16, 2012). 
organizations must establish, monitor and enforce legal norms actively and even-handedly. Private associations and institutes must develop and promulgate codes of conduct, particularly with respect to corporate directors, that raise expectations for behavior and generate formal and informal sanctions for failure to meet these expectations. Educational institutions should promote research on professional and managerial ethics. Institutions throughout government and society must educate and train persons ranging from judges to regulators to managers and to retail investors. Investment advisors and business media must constantly weigh information provided by companies and probe for additional information of interest to investors. This would not only benefit the society but would also be beneficial for the companies as well. It is required that the government must step in and ensure the effective implementation of Clause 49 of the Listing Agreement on corporate governance so that the interest of the investors must be protected as well as transparency in the corporate functioning may be maximised. But, it is imperative that governmental intervention must also be regulated i.e. it should be done sparingly and with utmost care and caution so as to ensure that corporate autonomy is not sabotaged. ${ }^{13}$ Though complying with the requirements of Clause 49 of Listing Agreement on corporate governance needs considerable effort on the part of the corporate managers, achieving this goal would bring governance of Indian companies at par with global corporate governance. Thus at the end it can be said that "a nation's well being, as well as its ability to compete, is conditioned by a single, pervasive cultural characteristic: the level of trust inherent in the society." 14

13 Shukla, supra note 5.

14 Ruben Kraiem, Leaving Money on the Table: Contract Practice in a Low Trust Environment, 42 COLUMN. J. TRANSNAT'L.L. 715, 716 (2004). 